\title{
PĂRINTELE ANDRE SCRIMA - UN MODEL DE MISIUNE CREŞTINĂ ÎN SPAȚIUL ISLAMIC
}

\author{
Oliviu-Petru Botoi*
}

\begin{abstract}
This paper illustrates an example of Christian mission within the Islamic area in the VII ${ }^{\text {th }}$ and VIII ${ }^{\text {th }}$ decades of the past century. André Scrima, a Romanian Orthodox monk, in his spiritual and intellectual itinerary, at the kindly request of the Lebanese Orthodox Youth, spends some time in Lebanon. His mission is reflected by his presence in the "Saint Georges" Monastery Deir el-Harf and the Universities „,Saint Esprit” of Kaslik and „Saint Joseph” of Beirut. The clerical and pastoral activity of father Scrima held at Deir el-Harf Monastery, represents a spiritual renewal for the Orthodoxy in Lebanon which led to the rediscovery of the Holy Scriptures and the patristic wit, thus the Eastern hesychast tradition of the mental prayer was transmitted. The research and the academic activity in the Lebanese university environment in a critical period of time that Lebanon was passing through, he helped the improvement of the relationship between Christians and Muslims.
\end{abstract}

Keywords: Fr. André Scrima, mission, history of religions, ecumenism, monastery Deir el-Harf, university

\section{Preliminarii}

Prin însăşi natura sa, Biserica este misionară. Întemeierea ei prin jertfa lui Hristos şi naşterea ei prin iradierea Duhului Sfânt din trupul

\footnotetext{
" PhD Candidate at Faculty of Orthodox Theology, "1 Decembrie 1918" University of Alba Iulia and Teacher of Literature and Theology at "St. Simion Ştefan" Orthodox Thelogical Seminary of Alba Iulia, Romania.
} 
hristic la Rusalii ${ }^{1}$, determină un continuu apostolat misionar de propovăduire sub lucrarea Sfântului Duh. De-a lungul secolelor, ethosul misionar al Bisericii poate fi creionat în funcție de contextul socio-istoric şi politic care a marcat într-o măsură diferită morfologia stilistică şi impactul realizat în toate palierele vieții sociale: cultură, artă, educație, familie, persoană, etc., „Biserica neputând rămâne pasivă la situațiile dezastruoase la care este supusă întreaga fire umană, recapitulată şi restaurată de Unicul Mântuitor, Iisus Hristos"2. Perioada contemporană, epoca de afirmare deplină a postmodernității propune şi impune în acelaşi timp o structură misionară diferită faţă de cele precedente, sau am putea spune într-un anume fel, mai apropiată de cea a Bisericii primare. Post-modernitatea pune față în față toate culturile şi religiile lumii, provocând un dialog inevitabil în care creştinismul, pe lângă exprimarea unei poziții, trebuie să făptuiască misiunea încredințată de Însuşi Mântuitorul: „Mergând, învățați toate neamurile, botezându-le în numele Tatălui şi al Fiului şi al Sfântului Duh, învățându-le să păzească toate câte vam poruncit vouă, şi iată Eu cu voi sunt în toate zilele, până la sfârşitul veacului. Amin" (Matei 28;19-20). A vorbi despre misiunea Bisericii presupune abordarea unor teme multiple din toate sferele disciplinelor teologice şi nu numai, deoarece misiunea foloseşte toate mijloacele interne prin care încearcă să îşi atingă scopul. Expunerea noastră se va opri asupra portretului unui misionar creştin pentru contextul socio-politic al vremurilor în care trăim. André Scrima, monahul şi intelectualul de formație universală, dar puternic înrădăcinat în propria-i tradiție, a trăit evenimentele modernității târzii, însă şi-a dat seama de noua structură a lumii anunțată de postmodernitate, dezvoltând o teologie vie şi trăită care interacționează

${ }^{1}$ Dumitru Stăniloae, Teologia Dogmatică Ortodoxă (II), Carte tipărită cu binecuvântarea Prefericitului Părinte Teoctist Patriarhul Bisericii Ortodoxe Române, Ediția a III-a, Bucureşti, Editura IBMBOR, 2003, pp. 202-203. Părintele Profesor Dumitru Stăniloae surprinde relația dintre Hristos-Duhul Sfânt-Biserică pentru pnevmatizarea lumii.

${ }^{2}$ Mihai Himcinschi, Biserica în societate. Aspecte misionare ale Bisericii $\hat{\imath} n$ societatea actuală, Alba Iulia, Editura Reîntregirea, 2006, p. 8. 
cu celelalte religii ale lumii, în special cu cele monoteiste. Misiunea Bisericii în diaspora nu ar trebui să privească doar asupra Occidentului în care se luptă cu umanismul secular şi relativismul moral, ci şi asupra Orientului, locul din care au pornit cele trei religii monoteiste, mai ales pentru faptul că astăzi, în acele locuri creştinii suferă cele mai multe asupriri şi lipsiri de drepturi din partea musulmanilor.

\section{Părintele André Scrima - schiță biografică $\breve{3}^{3}$}

Andrei Scrima s-a născut la 1 Decembrie 1930, în localitatea Gheorghieni, județul Covasna (în perioada interbelică, județul Ciuc). Familia sa era de origine macedoromână şi se stabilise în România în perioada interbelică. $\mathrm{Nu}$ a petrecut foarte mult timp în Ținutul Secuiesc, deoarece familia sa se mută la Orăştie şi apoi la Hunedoara. Aici începe şcoala înainte de a fi împlinit vârsta de şase ani, devenind mai apoi elev al liceului „Aurel Vlaicu” din Orăştie, fiind găzduit la o familie germană. La vârsta de doar zece ani îl citea pe Nietzsche şi se dezvolta ca un spirit contemplativ şi singuratic. Una din rugăciunile tinereții sale pe care şi-o amintea părintele

${ }^{3}$ În realizarea unui portret biografic al părintelui André Scrima am folosit doar bibliografia consacrată din limba română şi franceză. Printre cele mai semnificative articole care prezintă parcursul biografic al părintelui Scrima şi pe care le-am folosit şi noi, amintim: Prefaţa semnată de către domnul Andrei Pleşu la Timpul rugului aprins. Maestrul spiritual în tradiția răsăriteană, Volum îngrijit de Anca Manolescu, Bucureşti, Editura Humanitas, 2012, pp. 517; Vlad Alexandrescu, Note despre parcursul intelectual al lui André Scrima, în André Scrima, „O gândire fără țărmuri. Ecumenism şi globalizare”, Bucureşti, Editura Humanitas, 2004, pp. 132-143; Radu Bercea, Peregrinarea lui André Scrima, în André Scrima, „O gândire fără țărmuri...”; Olivier Clément, Note biographique, în „Contacts”, anul LV, nr. 203, iulie-septembrie 2003, pp. 243-245; Anca Vasiliu, André Scrima l'étranger, în „Contacts”, anul LVI, nr. 207, iulie-septembrie 2004, pp. 211-222; Valentin Cioveie, Părintele Andrei Scrima, în ,Tabor”, anul VII, nr. 3, martie 2013, pp. 71-84. 
Andrei era: „Păstrează-mă, Doamne, întotdeauna străin şi singur!”4 . Moartea neaşteptată a tatălui său din anul 1942, implică mutarea familiei la Bucureşti, unde, doar după câțiva ani va muri şi mama sa. Aflat la Bucureşti, îşi continuă studiile la liceul „Gheorghe Lazăr” pe care îl absolvă la cincisprezece ani. Se va înscrie apoi la Facultatea de Filozofie şi la Medicină, pe cea din urmă părăsind-o după un an. Ca student la Filozofie îl va întâlni pe profesorul Anton Dumitriu care va marca personalitatea tânărului Andrei. În 1948 va susține licența în filozofie cu tema „Logos şi dialectică la Platon”, teză ce poartă amprenta preferențială a profesorului său, însă şi presupune parcurgerea a numeroase surse filosofice antice şi studii critice moderne. În ultimii doi ani de facultate devine asistentul lui Anton Dumitriu $^{5}$ la catedra de Logică şi Istoria Filosofiei. În această perioadă frecventează şi cursurile Facultății de Matematică - Fizică, pe care nu o termină însă, sustrăgându-se chiar în pragul licenței de la un examen de marxism ${ }^{6}$. În apropierea aceluiaşi profesor va cunoaşte o serie de personalităţi ale vieții culturale şi religioase ale vremii: Alexandru Mironescu, Sandu Tudor, Grigore Moisil, Eugen Schileru, Marcel Avramescu, etc. Pe lângă componenta intelectuală pe care anturajul i-a insuflat-o, tânărului Scrima i s-a deschis şi drumul Antimului unde a fost introdus încă din 1946. Nu doar formația de şcoală l-a atras pe Scrima spre abisurile cunoaşterii, ci şi studiile individuale: citea marii Părinți Răsăriteni, marii teologi străini ai secolului XX (Jean Danielou, Henri de Lubac, Hans Urs von Balthasar), studii particular de sanscrită şi arabă, etc. Momentul de maximă importanţă în devenirea duhovnicească ulterioară a tânărului Andrei Scrima a fost marcat de întâlnirea sa cu Părintele Ioan cel Străin (Ivan Kulâghin), un preot refugiat în România între anii 1944-1946. Prin acesta din urmă, Andrei Scrima a primit tradiția

\footnotetext{
${ }^{4}$ Andrei Pleşu, Prefață la André Scrima, Timpul rugului aprins. Maestrul spiritual în tradiția răsăriteană, Prefaţă de Andrei Pleşu, Volum îngrijit de Anca Manolescu, Bucureşti, Editura Humanitas, 2012, p. 8.

${ }^{5}$ Valentin Cioveie, Părintele Andrei Scrima, în „Tabor”, anul VII, nr. 3, martie 2013, p. 74.

${ }^{6}$ Andrei Pleşu, op. cit, p. 8.
} 
isihastă rusească pe care o va păstra toată viața sa. Călugărul Ivan Kulâghin, privind spre Andrei Scrima, a întrebat „Cine este tânărul acesta?”, răspunzând retoric: „Simt că are nevoie de mine”" . Din acel moment viaţa lui Andrei Scrima s-a schimbat pentru totdeauna. În 1949 s-a înscris la Facultatea de Teologie Ortodoxă şi a fost primit ca frate la Mănăstirea Antim. Până în 1953 predă la Seminarul Monahal Superior de la Mănăstirea Neamț, unde va avea colegi de catedră părinţi precum: Benedict Ghiuş, Petroniu Tănase, Sofian Boghiu şi Arsenie Papacioc. După desființarea Seminarului de la Neamţ, Andrei Scrima revine la Bucureşti, unde sub ascultarea patriarhului Justinian va lucra împreună cu Bartolomeu Valeriu Anania la reorganizarea Bibliotecii Patriarhale. Pe lângă aceste preocupări cărturăreşti, tânărul Andrei Scrima petrece o perioadă de asceză la Mănăstirea Slatina, alături de viitorii mari părinți duhovniceşti ai României: părintele Ilie Cleopa, părintele Petroniu şi viitorul mitropolit Antonie Plămădeală. În această mănăstire, la 26 iulie 1956, este călugărit de către părintele Benedict Ghiuş. Atât din punct de vedere intelectual, cât şi spiritual, Scrima a avut privilegiul de a se forma în jurul unor oameni de excepție. Mult mai târziu, însuşi el va recunoaşte meritul întelectualilor care frecventau Rugul Aprins în formarea sa intelectuală şi deschiderea culturală ${ }^{8}$, precum şi providenţiala întâlnire cu călugărul rus şi compania unor tineri duhovnici care mai târziu vor reprezenta stâlpii de credință în păstrarea şi afirmarea ortodoxiei româneşti în perioada comunistă şi post-comunistă.

Profunzimea gândirii teologice se întrezărea încă din anii studenției în teologie. După studii temeinice de filozofie şi logică, pe lângă studiile de ştiințe exacte: matematică-fizică, Andrei Scrima se apropie de părintele Dumitru Stăniloae, sub coordonarea căruia realizează teza de licență cu tema „Schiță a unei antropologii

\footnotetext{
${ }^{7}$ Ibidem, p. 9.

${ }^{8}$ Vlad Alexandrescu, Note despre parcursul intelectual al lui André Scrima, în André Scrima, „O gândire fără țărmuri. Ecumenism şi globalizare”, Bucureşti, Editura Humanitas, 2004, p. 134.
} 
apofatice, în spiritul tradiției ortodoxe", continuând oarecum demersul profesorului său, în ceea ce priveşte adâncirea izvoarelor vii ale tradiției ortodoxe"10, demers patristic tratat în Cursul de ascetică şi mistică al părintelzui Stăniloae, pe care Scrima a intenționat la un moment dat să îl traducă în limba franceză.

Calitățile cărturăreşti şi duhovniceşti ale tânărului teolog 1-au adus repede în preajma patriarhului Justinian care îl simpatiza mult şi îl folosea ca translator pentru vizitele pe care le primea din străinătate. Aşa se întâmplă că Mohammad Habib, rectorul Universității din Aligarh (India) rămâne extrem de impresionat de cunoştinţele de indianistică şi sanscrită ale lui Andrei Scrima, motiv pentru care rectorul va cere pentru acesta o bursă de studiu Ministrului Culturii din India. În cele din urmă, ieşirea lui Scrima din țară se va datora însuşi preşedintelui Indiei, S. Radhakrishnan, care aflat într-o vizită în România, rămâne la fel de impresionat ,să audă un fraged călugăr ortodox recitând, în sanscrită din KathaUpanishad" ". Preşedintele Radhakrishnan îi oferă lui Andrei Scrima bursa cerută de rectorul Universătății din Aligarh, iar autorităţile comuniste sunt puse în faţa unui fapt împlinit. Înainte de a pleca în India, Scrima petrece câteva luni de zile la Institutul Ecumenic de la Bossey-Geneva (Elveția) unde va cunoaşte importanți teologi ai lumii occidentale cu care va rămâne permanent în legătură. Tot în acest timp va intra în contact cu personalitățile exilului rus de la Paris şi face un popas spiritual în Muntele Athos.

În India, sub îndrumarea profesorului T.R.V. Murti, lucrează la o teză de doctorat, The Ultimate, its Methodological and

\footnotetext{
${ }^{9}$ Ibidem, p. 10. Textul lucrării de licență a părintelui Scima, alături de cel al tezzei de doctorat, pregătită în India şi susţinută la Paris, poate fi consultat în ediția André Scrima, Antropologia apofatică, Volum îngrijit de Vlad Alexandrescu, Bucureşti, Editura Humanitas, 2005. În studiul domnului Vlad Alexandrescu, titlul lucrării de licență a lui Andrei Scrima poartă un nume uşor diferit: Încercare de introducere la o antropologie ortodoxă apofatică.

${ }^{10}$ Vlad Alexandrescu, op. cit, p. 136.

${ }^{11}$ Andrei Pleşu, op. cit., p. 10.
} 
Epistemological Connotation According to Advaita-Vedanta, însă refuză orice titlu academic.

În 1960 se va întoarece în Franța unde va dobândi cetățenia franceză, fiind legat multă vreme de această țară în care revenea constant din itinerariile sale dese. Chiar va ajunge ca între anii 19661966 să devină profesor la Universitatea Dominicană Le Saulchoir.

Viața marelui teolog este marcată de multe evenimente importante pentru toată lumea creştină. Se impune categoric să amintim de rolul pe care 1-a avut Scrima la Conciliul Vatican II. După ce în 1960 1-a cunoscut pe Patriarhul Athenagoras al Constantinopolului, acesta 1-a delegat ca participant la şedințele conciliului ca reprezentant al său personal, devenind astfel Arhimandrit al Patriarhului Ecumenic. De asemenea, tot în acest context al legăturii stabilite între Andrei Scrima şi Patriarhul Athenagoras, trebuie să consemnăm şi faptul că Scrima a avut un rol extrem de important în întîlnirea istorică de la Ierusalim, dintre capii celor două Biserici.

Un alt aspect care se impune a fi menționat este legat de activitatea sa ca vice-preşedinte al Acdemiei Înternaționale de Ştiințe Religioase şi Filozofie a Ştiinței de la Bruxelles. Î̉ itinerariul său spiritual şi intelectual se înscrie şi popasul pe pământul american, la Chicago, unde a fost invitat de către Mircea Eliade şi la Houston unde a fost consilier ştiințific. Aflat în Statele Unite, o întâlneşte pe Principesa Ileana, cea care în 1967 va îmbrăca haina monahismului şi va fonda o mănăstire ortodoxă la Ellwood-City (Pennsylvania) cu hramul „Schimbarea la Față”, a cărei stareță va rămâne pănă la sfărşitul vieții în 1991.

În 1991, după ce petrece din nou o scurtă vreme în India, de data aceasta la New Delhi, a simţit chemarea pământului românesc. Așa se face că părintele Scrima se întoarce acasă, prăznuind Sfintele Paști la Mănăstirea Antim de care a fost foarte legat în tinetețile sale. În România petrece aproape zece ani în care va întâlni foarte mulți intelectuali tineri, atât teologi cât şi laici, care au rămas fascinați de cunoştințele şi prospețimea gândirii teologice a părintelui Scrima. 
În 19 august 2000, trece la cele veşnice şi este înmormântat la Mănăstirea Cernica de lângă Bucureşti.

\section{Misiunea Părintelui André Scrima în Liban}

Cea mai importantă întâlnire a părintelui André Scrima cu religia islamică este cea din Liban. Deşi prin titlu, lucrarea de faţă îşi propune o radiografie a misiunii părintelui Scrima în spațiul islamic, totuşi ne vom limita doar la activitatea sa din Liban. Ecoul misiunii sale din Liban va influența întreg spațiul islamic, devenind astfel, un reper important al dialogului dintre cele două mari religii monoteiste: creştinismul, respectiv islamul. Am putea spune că viziunea părintelui Scrima referitoare la rolul religiilor monoteiste, importanţa cetăţii Ierusalimului, precum şi articularea verbală a Revelației Divine în scripturile celor trei religii, constituie un punct puternic de strategie misionară, ținând seama de contextul istoric actual din spațiul Orientului Apropiat şi Mijlociu. Mai mult decât atât, activitatea părintelui Scrima s-a desfăşurat în spațiul geografic care actualmente ridică cele mai multe probleme în ceea ce priveşte relaţia dintre creştini şi musulmani. Chiar dacă în Liban situaţia este sub control din acest punct de vedere, în teritoriul imediat vecin, anume în Siria, creştinii sunt supuşi frecvent unor violențe fizice şi psihice $^{12}$ pe care o societate modernă şi democratică nu le poate

${ }^{12}$ Frecvent se pot citi ştiri despre situaţia creştinilor din Siria, Iordania, Egipt, Kenya, Pakistan, Etiopia, Libia, etc., în care sunt prezentate ucideri de vieți omeneşti, privări temporare de libertate, distrugerea lăcaşurilor de cult şi a obiectelor cultice, reprimarea exprimării şi afirmării credinței creştine. Asemenea ştiri sunt difuzate de mari agenții de presă internationale: L'Etat islamique assassine 28 chrétiens en Libye,în „Le Monde”, 19 aprilie 2015 (http://www.lemonde.fr/recherche/?keywords=chretiens+tues\&qt=recherche_gl obale); Daech assassine des chrétiens d'Éthiopie, în „Le Figaro”, 20 aprilie 2015

(http://www.lefigaro.fr/international/2015/04/20/0100320150420ARTFIG00285-daech-assassine-des-chretiens-d-ethiopie.php)

Persecuted Church, în „The Times”, 24 decembrie 2014 (http://www.thetimes.co.uk/tto/opinion/leaders/article4305898.ece); Terror in Syrien: IS-Miliz lässt 19 Christen gegen Lösegeld frei, în „Die Spiegel”, 2 
tolera. Cele două state, Libanul şi Siria, după cum afirma şi preşedintele Hafez al-Assad al Siriei într-un celebru discurs din 20 iulie 1976, ,,au împărtăşit aceleaşi interese şi istorie comună"13, deşi istoria nu le-a privat de dispute şi conflicte armate în anii 1975$1976^{14}$.

Una dintre cele mai importante lucrări misionare la care a contribuit major părintele Scrima este legată de activitatea sa în mediul academic libanez. După plecarea sa din muntele Athos şi înainte de a se îndrepta spre New Delhi, André Scrima, face o escală la Beirut, unde a cunoscut un grup de intelectuali ortodocşi laici care doreau să trăiască o viață comunitară autentică. Aşa se face că în primăvara anului 1959, după periplul din India, ajunge în Liban. Misiunea părintelui Scrima în Liban relevează cel puțin două direcții: una de propovăduire a unui creştinism autentic cu accent pe trăirea mistică prin revirimentul monastic de la Mănăstirii „Sfântul Gheorghe"-Deir el-Harf, iar alta de cultivare a unui dialog interreligios prin cursurile predate la Universitatea „Saint Joseph” din Beirut şi la Universitatea ,Saint Esprit” din Kaslik.

martie 2015 (http://www.spiegel.de/politik/ausland/islamischer-staat-is-laesst19-assyrische-christen-frei-a-1021228.html).

${ }^{13}$ Daniela Dumbravă, Theology and History of Religions in the Middle East. A Brief Account: Fr. André Scrima, spiritual and peace mediator in Libanon (1970-1980), în Giulia Sfameni Gasparro, Augusto Cosentino, Mariangela Monaca (editori), „Religion in the History of European Culture”, Palermo, Officina di Studi Medievali, 2013, p. 601.

${ }^{14}$ Pentru o înţelegere eficientă a contextului istoric şi religios din acest areal geografic, vezi „O «facultate de Ştiințe Religioase» în spaţiul uman şi cultural al Libanului şi al Orientului Apropiat", în André Scrima, Teme ecumenice, Volum îngrijit şi introducere de Anca Manolescu, Traducere din limba franceză de Anca Manolescu, Traducere din limba engleză de Irina Vainovski Mihai, Bucureşti, Editura Humanitas, 2004, pp. 161-188. (în special capitolele „Putem încerca să abordăm în mod simplu o realitate complexă” şi „Credință şi instituții creştine").

Vezi şi Bassel Salloukh, Syria and Lebanon: A Brotherhood Transformed, în „Middle East Report, nr. 236, 2005, pp. 14-21. 


\subsection{Părintele Scrima - duhovnic al mănăstirii Deir el-Harf}

Chiar dacă istoria Mănăstirii Deir el-Harf ${ }^{15}$ este legată de o legendă ${ }^{16}$, totuşi începând cu secolul al XVIII-lea există dovezi scrise cu o listă de nume ale unor egumeni care au viețit în acea mănăstire şi care erau numiţi de către episcopul de Beirut. Date certe despre istoria mănăstirii ne stau la dispoziție începând cu anul 1939, atunci când Adele Kazan, devenită maica Anastasia a fondat o comunitate de călugărițe care şi-a luat numele de ,al-thaluth amaqdas" (a Preasfintei Treimi). Datorită opoziției unor preoți, nu şi-a putut duce misiunea la sfârşit şi a fost nevoită ca în 1941 să se retragă într-un sat din apropiere unde a întemeiat o şcoală care funcționează până în zilele noastre.

În 1949, arhimandritul Theodosius Montlaq a propus un proiect mitropolitului Byblosului şi Botyrisului, Elia Karam. Proiectul prevedea înființarea unei comunităţi monahale numite ,al-Fadi alSalih" (Bunul Mântuitor) care se vor dedica în totalitate rugăciunii şi educării tinerilor. De asemenea, arhimandritul Theodosius Montlaq spera să fondeze o asociație a laicatului care să susțină comunitatea monastică din punct de vedere financiar, contribuind în acelaşi timp şi la susținerea unei şcoli şi a unui orfelinat ce urmau să fie deschise. Planul este abandonat repede, deoarece la finele anului 1950, exista un singur novice alături de părintele arhimandrit, care la scurt timp se retrage din mănăstire. A mai existat o încercare în 1954, când un grup de tinere femei au încercat să trăiască în mănăstire, însă după

\footnotetext{
15 Despre istoria Mănăstirii „Sfântul Gheorghe”-Deir el-Harf nu se cunosc multe lucrări în literatura de specialitate europeană. Singura lucrare de care am aflat şi care nu ne-a putut sta la îndemână este Houda Kassatly, $L a$ CommunauteMonastique de Deir el-Harf, Lebanon-Univerité de Balamand, 1996.

16 „Un tânăr din Munții Libanului a fost obligat de familie să se căsătorească cu verişoara sa împotriva convingerilor sale creştine. A dorit să-şi dedice viaţa lui Iisus şi a fondat Mănăstirea Deir el-Harf în inima Libanului. Se spune, de asemenea, că în acel loc ar fi existat un locaş de rugăciune din secolul al V-lea, ridicat pe ruinele unui templu păgân."
} 
câteva luni au preferat să se mute la mănăstirea Mar Yacoub din Koura, în partea de nord a Libanului.

Adevăratul reviriment monastic şi duhovnicesc se leagă de numele părintelui André Scrima. Numeroşi membri ai Mişcării Tineretului Ortodox si-au arătat intenția de a cunoaşte viața mistică şi de a intra în viața monahală, organizându-se într-un mod rudimentar în mănăstirea Deir el-Harf. Treburile gospodăreşti erau îndeplinite prin implicarea câtorva tineri carismatici, sirieni şi libanezi: Chafic Mansour, Elia Yaccoub, Habib Fahde şi Marcel Morcos. Chiar dacă au fost îndrumați spiritual de către părintele Daoud el-Mur, totuşi se simțea lipsa unei vieți monastice autentice şi profunde. Din acest motiv, aşa cum am arătat şi mai sus, i s-a cerut părintelui Scrima care era încă în India, să se stabilească în Liban pentru ca aceşti tineri aprinşi de flacăra vieții mistice să poată profita de experiența şi cunoştințele sale ${ }^{17}$. Astfel, în Duminica Floriilor, părintele André Scrima soseşte la Mănăstirea Deir el-Harf din Liban, marcând „legătura dintre tradiția monastică, preluată pe filieră românească, şi renaşterea noii vieți spirituale de pe pâmântul libanez"18. Activitatea părintelui Scrima la mănăstirea Deir el-Harf a fost foarte importantă pentru viața spirituală ortodoxă din Liban. Aici a primit taina hirotoniei ${ }^{19}$ întru preot de la episcopul locului, Elia Karam Ca duhovnic al acestei mănăstiri, s-a preocupat îndeaproape de urcuşul duhovnicesc al celor ce doreau să cunoască

${ }^{17}$ Samuel Noble, Monastic Renewal in Lebanon: Deir el-Harf, în „Notes on Arab Orthodoxy", luni, 27 iulie 2009 (ediție electronică). Pentru mai multe detalii privind prezentarea contextului în care se afla ortodoxia sub dominația musulmană, vezi Samuel Nobler, Alexander Treiger (edit.), The Orthodox Church in the Arab World, 700-1700. An anthology of sources, Northen Illinois University Press, 2014.

${ }^{18}$ Samuel Noble, Monastic Renewal....

19 Vezi expunerea părintelui Scrima, L'homme rené de l'Esprit dans la vie liturgique, prezentată cateheților de la Notre Dame des Dons, la Deir el-Harf. Textul poate fi citit ]n volumul André Scrima, Biserica liturgică, Volum îngrijit de Anca Manolescu, Traducere din franceză, cuvânt-înainte şi note de Anca Manolescu, Prefaţă de Mihail Neamțu. Bucureşti, Editura Humanitas, 2005, pp. $25-44$. 
ortodoxia. Tot ceea ce învăţa şi predica pornea ,dintr-o credință totală în Dumnezeu"20, fapt simțit de foarte mulți dintre ucenicii săi. Călăuzirea fiilor săi duhovniceşti nu era caracterizată de o rigoare a ascultării totate față de duhovnic în detrimentul unei desoperiri personale a prezenței lui Hristos şi a lucrării Duhului Sfânbt în viaţa fiecărui creștin, ci părintele încerca să stârnească în sufletul fiecărei persoane o scânteie care să aprindă dorul după Dumnezeu. În acest fel, pe lângă săvârşirea sfintelor slujbe şi activitatea pur spirituală, părintele André era un adevărat catehet şi bun predicator ${ }^{21}$ şi ținea mici seminarii cu cei care doreau să se inițieze în credință $\breve{c}^{22}$. Ucenicii lui mărturisesc faptul că după o curăţire de patimi şi păcate şi după începutul unui efort ascetic asumat, părintele Scrima începea să le vorbească despre dobândirea Duhului Sfânt prin rugăciunea neîncetată. Aşa se face că ucenicii săi din Liban, de diferite naționalități, au descoperit rugăciunea lui Iisus ${ }^{23}$ prin care au simțit mai profund frumusețea Ortodoxiei. Dorul după rugăciune şi viață ascetică era antrenat prin lectura Sfintei Scripturi ${ }^{24}$ şi a literaturii patristice $^{25}$. După cum mărturiseşte sora Noëlle Devilliers, una dintre ucenicețele părintelui, citirea Sfintei Scripturi a însemnat pentru ea un efort ascetic intens pe care 1-a înțeles treptat. Odată cu dobândirea unei ,inteligențe spirituale”26, Duhul Sfânt prin cuvintele Scripturii locuieşte permanent în fiecare şi ne luminează acțiunile. Pentru acest fapt, Noëlle Devilliers a înțeles de la părintele Scrima că citirea Sfintelor Scripturi nu este un act rațional de cunoaştere şi

${ }^{20}$ Père Elie de Deir el-Harf, Témoignage, în „Contacts”, anul LV, numărul 203, iulie-septembrie 2003, p. 246.

${ }^{21}$ Ibidem, pp. 254-262. Aici se găsesc câteva omilii scurte ale părintelui Scrima rostite la diferite sărbători sau duminici.

${ }^{22}$ Ibidem, p. 247.

${ }^{23}$ Noëlle Devilliers, Ce que fut dans ma vie la rencontre du père André Scrima, în „Contact”, anul LV, numărul 203, iulie-septembrie 2003, p. 265.

${ }^{24}$ Ibidem, p. 270.

${ }^{25}$ Ibidem, p. 265. Părintele Scrima încerca ca prin citirea literaturii patristice, în special Apoftegmele Sfântului Antonie cel Mare, fiecare să perceapă şi să descopere în text un ,ritm intern” care să-i mențină treji în viața duhovnicească. ${ }^{26}$ Ibidem, p. 270. 
anamneză, ci un moment de rugăciune ${ }^{27}$ şi luminare spirituală prin lucrarea Duhului Sfânt în mintea şi sufletul nostru. Din această perioadă a vieții sale ne-a rămas o veritabilă exegeză scripturistică, „o hermeneutică în act” a Evangheliei după Ioan ${ }^{28}$. Monahii mănăstirii transcriau omiliile părintelui din limba franceză în limba arabă (1964-1965), urmând ca în anul 1988, prima parte a exegezei, cuprinzând capitolele 1-17, să fie publicată la Editura An-Nur din Beirut. Capitolele următoare, 18-21, au fost tâlcuite mai târziu (1985-1986) şi s-au păstrat înregistrate în limba franceză.

Chiar dacă părintele André Scrima a fost şi un intelectual rafinat şi un veritabil universitar, aşa cum vom arăta în subcapitolul următor, acest lucru nu 1-a privat deloc de efortul ascetic călugăresc şi nu i-a înlesnit urcuşul duhovnicesc, după cum mărturisesc cei care 1-au cunoscut în mănăstire:

„,se spune (despre André Scrima n.n.) că era mai degrabă un om de ştiinţă şi filosof decât un om duhovnicesc. Însă cei care l-au cunoscut de aproape ştiu bine că mai înainte de toate era un om duhovnicesc. Vasta sa cultură tindea către Cunoaşterea adevărată, cea a spiritului. Am putea spune că toată ştiința sa se transmuta din planul intelectual la nivelul Spiritului. Ne spunea că realitatea spirituală era mai reală ca orice altă realitate" 29 .

Misiunea de propovăduire a unei trăiri autentice în spiritul deplin şi profund al Ortodoxiei nu s-a limitat doar la acest spațiu

${ }^{27}$ Sora Noëlle Devilliers mărturiseşte că „niciodată nu l-am înțeles pe părintele André Scrima predicând. Însă, iată că el m-a învățat să citesc Scriptura aşa cum o citea el însuşi, după exegeza tradițională ortodoxă, cea a Părinților Bisericii şi care oferă o «inteligenţă spirituală» a cuvintelor şi a actelor lui Hristos prin citirea rugăciunii pe care o rosteşte preotul înainte de citirea Evangheliei la Sfânta Liturghie" (Noëlle Devilliers, Ce que fut dans ma vie la rencontre du père André Scrima, în „Contact”, anul LV, numărul 203, iulie-septembrie 2003, p. 270).

${ }^{28}$ André Scrima, Comentariu integral la Evanghelia după Ioan, Traducere din arabă de Monica Broşteanu, Traducere din franceză de Anca Manolescu, Bucureşti, Editura Humanitas, 2008.

${ }^{29}$ Père Elie de Deir el-Harf, art. cit., p. 246. 
geografic. Peste tot pe unde a trecut a lăsat în urmă ,tămâia trăirii ortodoxe", făcând cunoscută în Europa (în Franța mai ales) şi în Statele Unite tradiția ortodoxă şi importanța călăuzirii spirituale în duhul patristic răsăritean ${ }^{30}$.

\subsection{Misiunea părintelui Scrima în mediul universitar libanez}

După doar câțiva ani petrecuți în Liban, părintele Scrima a fost învitat să predea cursuri la Universitatea maronită „Saint Esprit” din Kaslik. În cadrul Institutului Superior de Liturgică al Universitătiii a predat cursurile: La théologie de l'office byzantin (Teologia oficiului liturgic bizantin), L'Epiphanie dans la tradition liturgique byzantine (Epifania în tradiția liturgică bizantină), L'office de la Pentecôte byzantine. Analyse structurale et thématique (Liturgica bizantină a Cincizecimii. Analiză structurală şi tematicăa $)^{31}$, Aperçussur l'hésichasme (O expunere sintetică a isihasmului) ${ }^{32}$.

Începând cu anul 1971, a fost invitat să țină cursuri şi la Universitatea „Saint Joseph” din Beirut, universitate care va rămâne întotdeauna legată şi de numele părintelui André Scrima. Aici a predat în primă fază trei cursuri: filozofie comparată, teologie dogmatică creştină şi istoria religiilor ${ }^{33}$. La această universitate va întâlni trei persoane de care va rămâne legat o lungă perioadă de timp: preotul iezuit Augustin Dupré la Tour şi teologii musulmani suniţi, prof. Hisham Nashabé şi prof. Yūsuf Ībish. Profesorul

\footnotetext{
${ }^{30}$ Este notabilă relatarea şederii părintelui Scrima la abația Mont-de-Cats, acolo unde din când în când cu aprobarea superiorilor, săvârşea liturghia ortodoxă în mijlocul călugărilor catolici care au rămas uimiţi de frumusețea cultului şi atinşi de harul Duhului Sfânt care lucra prin cuvântul părintelui. Vezi, Noëlle Devilliers, art. cit., pp. 268-269.

${ }^{31}$ André Scrima, Biserica liturgică....., pp. 44-315.

32 André Scrima, Despre isihasm, Volum îngrijit de Anca Manolescu, Traducere din franceză de Maria Cornelia Ică, Anca Manolescu, Toader Saulea, Traducere din engleză de Sorana Corneanu, Bucureşti, Editura Humanitas, 2003, pp. 62-152.

${ }^{33}$ Daniela Dumbravă, art. cit., p. 602.
} 
Hisham Nashabé, care încă se află în viață, evocă contextul întâlnirii sale cu părintele Scrima de la Mănăstirea Deir el-Harf:

„Circumstanţele ce au dus la întâlnirea dintre mine şi părintele Scrima sunt foarte speciale. Era în timpul Războiului Civil din Liban. Toată lumea lupta. Oraşul era aproape paralizat. În această atmosferă de conflict, de luptă, de jur-împrejur, era acest om care vorbea despre pace, dragoste, dialog, prietenie."34

Ţinând seama de contextul social şi religios al Libanului, cei trei amintiți mai sus, alături de părintele Scrima au înființat în 1974 un departament, devenit ulterior institut, de studii creştino-islamice, finanțat de către Dominiqué de Ménil, o faimoasă colecționară de artă care împreună cu soțul său deținea Ménil Collection şi Rothko Capel din Texas. După terminarea războiului civil, începând cu anul academic 1977-1978, institutul pune la dispoziția studenților câteva cursuri inedite ca temă, dar şi ca mod de abordare: „Experiența spirituală şi limbajul ei” şi ,Mişcări contemporane de înnoire în islam şi în creştinism"35, primul predat de către André Scrima, respectiv Yūsuf Ībish, iar al doilea de către Augustin Dupré la Tour şi Hisham Nashabé. Pe lângă cele două cursuri amintite, după 78, părintele Scrima ține şi alte două cursuri pentru studenţii libanezi: „Conştiința credinței exercită ea o funcție critică față de «ordinea lumii»»? şi „Ideologie şi utopie”. Noutatea perspectivei de abordare a cursurilor oferite consta în faptul că erau predate de către doi profesori de credinţe diferite care vorbeau despre aceeaşi temă. În timp, aceste cursuri şi-au dovedit eficacitatea, semănând în sufletele studenţilor atât o reverberaţie spirituală şi oferind modele de convivialitate şi interacțiune paşnică inter-religioasă şi

\footnotetext{
${ }^{34}$ Textul este reprodus din documentarul Andrei Scrima în Liban apărut în luna februarie a acestui an şi realizat de către domnul Radu Găină cu sprijinul Blombank şi a Ambasadei României în Liban.

${ }^{35}$ André Scrima, Experiența spirituală şi limbajele ei, Volum îngrijit de Anca Manolescu în colaborare cu Radu Bercea, Cuvânt înainte de Anca Manolescu, Traducere din limba franceză şi engleză şi note de Anca Monaolescu, Bucureşti, Editura Humanitas, 2008, pp. 15-16.
} 
interculturală. Aceste cursuri nu au doar o referențialitate locală sau regională, tratând probleme ale Libanului şi ale Orientului Apropiat, ci ,au drept de studiu chipul modernităţii târzii şi raportarea credinței - în stare de luciditate inspirată sau reflexivă - la acest chip. Ele crecetează distanța participativă sau conflictuală a religie față de cea mai recentă configurație a civilizației occidentale" ${ }^{36}$. Deja dinaintea anilor 70, Europa a fost silită să încerce să adopte o atitudine față de asiatici, africani şi sud-americani care se stabileau pe teritoriul european. Deschiderea faţă de alte culturi şi religii printr-un ecumenism greşit înțeles a generat un ,consumism cultural şi religios" care rupt legătura credinciosului cu Trupul tainic al Bisericii sale, ajungându-se astfel la ceea ce Grace Davie numea: Believing without belonging ${ }^{37}$ în care ,nu mai există cultură, ci culturi; nu mai există religie, ci religii şi religiozități; nu mai există nici modă, ci numeroase mode simultane, din care individul îşi poate alege şi combina propria identitate" ${ }^{, 38}$. Părintele Scrima a încercat să realizeze o delimitare ortodoxă între sfera credinței şi a religiei, printr-un efort de resuscitare a credinței a omului modern şi postmodern, iar mai apoi urmând de la sine o afirmare a religiei şi religiozității asumate, îndepărtând astfel religia de tip cultural, ocazional, festiv sau istoric şi religia ,îmburghezită”.

Unul dintre studenții de atunci ai Facultăţii de Teologie, devenit astăzi chiar rectorul Universităţii „Saint Joseph” din Beirut, dr. Salim Daccache, îşi aminteşte cu emoție de cursurile susținute de părintele Scrima şi de convorbirile avute cu el:

„L-am întâlnit pe părintele André Scrima în timp ce eram student la Facultatea Teologică a Universității „Saint Joseph”, între anii 1969-1974. Preda acolo şi mi-a fost profesor. Am vorbit mult cu

\footnotetext{
${ }^{36}$ André Scrima, Funcția critică a credinței, Prefață, traducere din franceză, note şi îngrijirea volumului de Anca Manolescu, Bucureşti, Editura Humanitas, 2011, p. 6.

${ }^{37}$ Grace Davie, Religion in Britain Since 1945: Believing Without Belonging, Oxford, Basil Blackwell, 1994.

${ }^{38}$ André Scrima, Funcția critică..., p. 6.
} 
el despre învăţământ. Cred că am fost la două sau trei cursuri ale sale. Îi plăcea să vorbească, se exprima calm, seren despre viaţa spirituală, teologică, despre multe lucruri. Ne strângeam în jurul lui ca să-i punem întrebări. Era un fel de maestru spiritual, de maestru în teologie şi un bun cunoscător al Bisericilor noastre: Biserica Maronită, Catolică, Greacă, Bizantină. Vorbea cu o voce foarte profundă şi blândă. Era plăcut să-l asculți.,"39

Cursurile susținute de către André Scrima în mediul academic libanez, nu se reduc doar la o dimensiune locală, la o intervenție spontană legată de timp şi spațiu pentru a depăşi o problemă socială de natură religioasă sau pentru a elimina un conflict între două tradiții religioase. Profunzimea şi teologia adâncă de care sunt impregnate cursurile ținute de părintele Scrima rămân pentru totdeauna repere pentru un dialog între cele două mari religii monoteiste în spiritul universal al Ortodoxiei.

\section{Concluzii}

Părintele arhimandrit André Scrima, prin toată activitatea şi prin însăşi persoana sa, a fost un ,ambasador” al Ortodoxiei în dialogul cu religiile şi culturile eterodoxe ale lumii. Deşi părintele Scrima se remarcă ca fiind un om de formație universală, peregrinându-se de-a lungul vieții sale pe trei continente (Europa, Asia şi America) şi încercând să înțeleagă pănă la profunzimile posibile şi alte tradiții religioase (islamul, iudaismul, hinduismul), totuşi rămâne extrem de fidel formației sale de monah ortodox. Experiența din țară a „Rugului aprins” alături de marii intelectuali şi viitorii mari duhovnici şi întâlnirea sa cu monahul rus Ioan cel Străin au marcat pentru totdeauna conştiința teologică a lui Scrima. De bună seamă că în receptarea părintelui nu lipsesc o serie de critici şi prejudecăți cu un aparent fundament, venite din partea „tradiţionaliştilor rigorişti” şi a „,conformiştilor de instituție”. În ceea ce-l priveşte pe părintele Scrima, a-1 judeca doar după o parte din

${ }^{39}$ Text reprodus din filmul documentar amintit, Andrei Scrima în Liban. 
acțiunile şi demersurile sale care nu se încadrează formal pe linia conformistă a unei optici vetuste reprezintă o înțelegere deformată a credinței şi implicit a religiei. După părerea noastră, nici măcar dialectica speculație a inclasabilității nu-1 poate surprinde total pe părintele Scrima. Evadarea lui André Scrima din sfera clasabilului produce o oarecare criză în procesul poziționării lui într-o matrice tradițională, fie a monahului, fie a intelectualului. Sub aspectul credinței, părintele Scrima, nu ar trebui supus unui examen critic după baremul scolastic al confesionalismului ce caracterizează perioada modernă şi post-modernă. În acest fel, un cleric misionar intelectual se transformă înntr-un iezuit, un mistic creştin devine un orientalist sincretist iar un spirit deschis spre „,celălalt” care este „străin” faţă de tine capată iz de francmason.

În cele din urmă, părintele Scrima reprezintă un model unic de la care se poate revendica lesne o misiune creştină eficientă, mai ales într-un spațiu impregnat de tradiții musulmane sau iudaice. Cunoaşterea lui Dumnezeu şi a Fiului Său ca fundament al vieții veşnice (Evanghelia după Ioan 17;3) a reprezentat o constantă a vieții părintelui Scrima. Cunoştințele vaste din culturile lumii au fost bine tescuite printr-o mistică asumată permanent care a lăsat să cadă vălul obscur al neînțelegerii şi ,vederea Fiului lui Dumnzeu” ca Răscumpărător şi Mântuitor universal al întregii creații.

Spiritul misionar al arhimandritului Scrima se mulează după strategia Apostolului neamurilor care a fost nevoit să se confrunte cu multiple culturi şi tradiţii religioase din acelaşi spațiu geografic. În Epistola către Corinteni, capitolul 9 , versetele $16-23^{40}$, apostolul

40 „Căci dacă vestesc Evanghelia, nu-mi este laudă, pentru că stă asupra mea datoria. Căci, vai mie dacă nu voi binevesti! Căci dacă fac aceasta de bună voie, am plată; dar dacă o fac fără voie, am numai o slujire încredințată. Care este, deci, plata mea? Că, binevestind, pun fără plată Evanghelia lui Hristos înaintea oamenilor, fără să mă folosesc de dreptul meu din Evanghelie. Căci, deşi sunt liber față de toți, m-am făcut rob tuturor, ca să dobândesc pe cei mai mulți; $\mathrm{Cu}$ iudeii am fost ca un iudeu, ca să dobândesc pe iudei; cu cei de sub lege, ca unul de sub lege, deşi eu nu sunt sub lege, ca să dobândesc pe cei de sub lege; $\mathrm{Cu}$ cei ce n-au Legea, m-am făcut ca unul fără lege, deşi nu sunt fără Legea lui 
Pavel ne spune că vestirea Evangheliei lui Hristos presupune o înțelegere profundă a lucrurilor pentru a-i putea câş̧tiga pe toți pentru Hristos:

„Căci, deşi sunt liber față de toți, m-am făcut rob tuturor, ca să dobândesc pe cei mai mulți; $\mathrm{Cu}$ iudeii am fost ca un iudeu, ca să dobândesc pe iudei; cu cei de sub lege, ca unul de sub lege, deşi eu nu sunt sub lege, ca să dobândesc pe cei de sub lege; $\mathrm{Cu}$ cei ce n-au Legea, m-am făcut ca unul fără lege, deşi nu sunt fără Legea lui Dumnezeu, ci având Legea lui Hristos, ca să dobândesc pe cei ce n-au Legea; $\mathrm{Cu}$ cei slabi m-am făcut slab, ca pe cei slabi să-i dobândesc; tuturor toate mam făcut, ca, în orice chip, să mântuiesc pe unii."

Aşadar, oricum am privi personalitatea şi activitatea părintelui Scrima, un lucru rămâne cert. În contextul crizei relațiilor dintre creştinii şi musulmanii din Orientul Apropiat, misiunea sa rămâne un model şi un reper pentru încercarea de a atenua conflictele dintre cele două religii.

\section{Bibliografie:}

1. Biblia sau Sfânta Scriptură, Tipărită sub îndrumarea şi cu purtarea de grijă a Prea Fericitului Părinte Teoctist Patriarhul Bisericii Ortodoxe Române, $\mathrm{Cu}$ aprobarea Sfântului Sinod, Bucureşti, Editura Institutului Biblic şi de Misiune al Bisericii Ortodoxe Române, 2002.

2. Alexandrescu, Vlad, Note despre parcursul intelectual al lui André Scrima, în André Scrima, „O gândire fără țărmuri. Ecumenism şi globalizare", Bucureşti, Editura Humanitas, 2004, pp. 132-143.

3. Bercea, Radu, Peregrinarea lui André Scrima, în André Scrima, „O gândire fără țărmuri. Ecumenism şi globalizare”, Bucureşti, Editura Humanitas, 2004, pp. 111-121.

Dumnezeu, ci având Legea lui Hristos, ca să dobândesc pe cei ce n-au Legea; $\mathrm{Cu}$ cei slabi m-am făcut slab, ca pe cei slabi să-i dobândesc; tuturor toate m-am făcut, ca, în orice chip, să mântuiesc pe unii. Dar toate le fac pentru Evanghelie, ca să fiu părtaş la ea." (Epistola către Corinteni, IX, 16-23) 
4. Cioveie, Valentin, Părintele Andrei Scrima, în „Tabor”, anul VII, nr. 3, martie 2013, pp. 71-84.

5. Clément, Olivier, Note biographique, în „Contacts”, anul LV, nr. 203, iulie-septembrie 2003, pp. 243-245

6. Devilliers, Noëlle, Ce que fut dans ma vie la rencontre du père André Scrima, în „Contact”, anul LV, numărul 203, iulie-septembrie 2003, pp.

7. Dumbravă, Daniela, Theology and History of Religions in the Middle East. A Brief Account: Fr. André Scrima, spiritual and peace mediator in Libanon (1970-1980), în Giulia Sfameni Gasparro, Augusto Cosentino, Mariangela Monaca (editori), ,Religion in the History of European Culture", Palermo, Officina di Studi Medievali, 2013, pp. 597-610.

8. Himcinschi, Mihai, Biserica în societate. Aspecte misionare ale Bisericii în societatea actuală, Alba Iulia, Editura Reîntregirea, 2006.

9. Père Elie de Deir el-Harf, Témoignage, în "Contacts", anul LV, numărul 203, iulie-septembrie 2003, pp. 246-262.

10. Salloukh, Bassel, Syria and Lebanon: A Brotherhood Transformed, în „Middle East Report, nr. 236, 2005, pp. 14-21.

11. Samuel Noble, Monastic Renewal in Lebanon: Deir el-Harf, în „Notes on Arab Orthodoxy", luni, 27 iulie 2009.

12. Scrima, André, Antropologia apofatică, Volum îngrijit de Vlad Alexandrescu, Bucureşti, Editura Humanitas, 2005.

13. Idem, Biserica liturgică, Volum îngrijit de Anca Manolescu, Traducere din franceză, cuvânt-înainte şi note de Anca Manolescu, Prefaţă de Mihail Neamţu. Bucureşti, Editura Humanitas, 2005.

14. Idem, Comentariu integral la Evanghelia după Ioan, Traducere din arabă de Monica Broșteanu, Traducere din franceză de Anca Manolescu, Bucureşti, Editura Humanitas, 2008.

15. Idem, Experiența spirituală şi limbajele ei, Volum îngrijit de Anca Manolescu în colaborare cu Radu Bercea, Cuvânt înainte de Anca Manolescu, Traducere din limba franceză şi engleză şi note de Anca Monaolescu, Bucureşti, Editura Humanitas, 2008.

16. Idem, Teme ecumenice, Volum îngrijit şi introducere de Anca Manolescu, Traducere din limba franceză de Anca Manolescu, Traducere din limba engleză de Irina Mihai, Vainovski, Bucureşti, Editura Humanitas, 2004.

17. Idem, Timpul rugului aprins. Maestrul spiritual în tradiția răsăriteană, Volum îngrijit de Anca Manolescu, Bucureşti, Editura 
Humanitas, 2012.

18. Stăniloae, Dumitru, Teologia Dogmatică Ortodoxă (II), Carte tipărită cu binecuvântarea Prefericitului Părinte Teoctist Patriarhul Bisericii Ortodoxe Române, Ediția a III-a, Bucureşti, Editura IBMBOR, 2003.

19. Vasiliu, Anca, André Scrima l'étranger, în „Contacts”, anul LVI, nr. 207, iulie-septembrie 2004, pp. 211-222.

\section{Webografie:}

1. L'Etat islamique assassine 28 chrétiens en Libye,în „Le Monde”, 19 aprilie 2015 (http://www.lemonde.fr/recherche/?keywords=chretiens+tues\&qt=rec herche_globale).

2. Persecuted Church, în „The Times”, 24 decembrie 2014 (http://www.thetimes.co.uk/tto/opinion/leaders/article4305898.ece).

3. Terror in Syrien: IS-Miliz lässt 19 Christen gegen Lösegeld frei, în „Die Spiegel”, 2 martie 2015 (http://www.spiegel.de/politik/ausland/islamischer-staat-is-laesst-19assyrische-christen-frei-a-1021228.html).

4. Daech assassine des chrétiens d'Éthiopie, în „Le Figaro”, 20 aprilie 2015 (http://www.lefigaro.fr/international/2015/04/20/0100320150420ARTFIG00285-daech-assassine-des-chretiens-dethiopie.php). 